\title{
The stronger is the belief the lower is the fear of death from COVID-19 pandemic
}

\author{
Caksen $\mathrm{H}$ \\ Division of Behavioral-Developmental Pediatrics, Department of Pediatrics, Necmettin Erbakan \\ University, Meram Medical Faculty, Meram, Konya, Turkey. huseyincaksen@hotmail.com
}

Text in PDF www.elis.sk

To the editor

The COVID-19 pandemic triggered feelings of fear, worry, anxiety, stress, depression and suicidal thoughts as responses to an extreme threat for the community and the individual (1). Herein, we present our observations on fear of death caused by the COVID-19 pandemic to emphasize the effect of belief on death fear.

Pradhan et al (2) noted that neuroticism was positively correlated to death anxiety; however, the relationship was completely mediated by perceived stress in the COVID-19 pandemic. In another study, positivity had a significant direct effect on death distress and happiness in the COVID-19 outbreak. Positivity mediated the effect of perceived risk on death distress and happiness (3). Rababa et al (4) found that religious coping and spiritual well-being were found to be significant predictors of death anxiety in older adults during the COVID-19 pandemic. The majority of the participating older adults were found to have low levels of religious coping and spiritual well-being and high levels of death anxiety (4). It has been reported that spiritual and religious affiliation could protect the individual from the emerging suicidal thoughts during the COVID-19 outbreak (1). In our daily practice, we have noted that most people were afraid of death due to the COVID-19 pandemic. However, we have seen some religious people, who did not fear death and were always ready for death because they believed the following religious teachings: Death is not terrifying as it appears to be superficially. For believers, death is to be discharged from the burdensome duties of life. For them it is a rest from worship, which forms the instruction and training in the arena of trial of this world. It also means rejoining their friends and relationships, ninety-nine out of a hundred of whom have already departed for the next world. It also means entering their true homeland and eternal abodes of happiness. It is also an invitation to the gardens of Paradise from the dungeon of this world. And it is the time they

Address for correspondence: $\mathrm{H}$. Çaksen, Prof, MD, PhD, Division of Behavioral-Developmental Pediatrics, Department of Pediatrics, Necmettin Erbakan University, Meram Medical Faculty, 42080 Meram, Konya, Turkey.

Phone: +90.332 .2236684$ receive their wage from the munificence of the Most Compassionate Creator in return for service rendered to Him. Since the reality of death is this, it should be regarded not as terrifying, but on the contrary as the introduction to mercy and happiness (5).

In conclusion, we would like to emphasize that the stronger is the belief the lower is the fear of death from COVID-19 pandemic. One, who does not recognize God is afflicted by a worldfull of tribulations. While the world of one who does recognize Him is full of light and spiritual happiness; he perceives these in accordance with the strength of his belief (5).

\section{References}

1. Fountoulakis KN, Exadactylos A, Anastasiadis K, Papaioannou N, Javed A. The international initiatives of the collaboration between the Aristotle University of Thessaloniki School of Medicine, the Panhellenic Medical Association and the World Psychiatric Association, concerning mental health during the COVID-19 outbreak. Psychiatriki 2020; 31 (4): 289-292.

2. Pradhan M, Chettri A, Maheshwari S. Fear of death in the shadow of COVID-19: The mediating role of perceived stress in the relationship between neuroticism and death anxiety. Death Stud 2020: 1-5. DOI: 10.1080/07481187.2020.1833384.

3. Yildirim M, Güler A. Positivity explains how COVID-19 perceived risk increases death distress and reduces happiness. Pers Individ Dif 2021; 168: 110347. DOI: 10.1016/j.paid.2020.110347.

4. Rababa M, Hayajneh AA, Bani-Iss W. Association of death anxiety with spiritual well-being and religious coping in older adults during the COVID-19 pandemic. J Relig Health 2021; 60 (1): 50-63.

5. Nursi BS. From the Risale-i Nur Collection. The Flashes [Internet]. Istanbul: Söz; 2012. The twenty-fifth flash. First chapter [cited 2021 March 17]. http://www.erisale.com/index.jsp?locale=en\# content.en.203.271

Received March 17, 2021. Accepted April 29, 2021. 